\title{
Simulation of Intensity, Track and Landfall of Tropical Cyclonic Storm Roanu over the Bay of Bengal Using WRF-ARW Model
}

\author{
Ariful Alam¹, Shammy Ahmed², Sharmin Rahman¹, Umme Habiba , Muhammad Abul Kalam \\ Mallik $^{3}$, S. M. Quamrul Hasan ${ }^{3}$ and Md. Abdul Mannan Chowdhury ${ }^{2}$ \\ ${ }^{1}$ Department of Physics, Mawlana Bhashani Science and Technology University, Tangail, Bangladesh \\ ${ }^{2}$ Department of Physics, Jahangirnagar University, Savar, Bangladesh. \\ ${ }^{3}$ Storm Warning Center, Bangladesh Meteorological Department, Dhaka, Bangladesh \\ Manuscript received: 21 April 2021; accepted for publication: 23 August 2021
}

\begin{abstract}
Almost every year, tropical cyclone forms over the Bay of Bengal in pre-monsoon and post-monsoon which strikes Bangladesh coast and the east coast of India. As the full thermodynamic features of a cyclone is not solved yet, an attempt has been made to simulate the track and landfall of cyclonic disturbances over the Bay of Bengal by using Weather Research and Forecasting (WRF) model. The WRF model (version 3.8) was run in a single domain of $20 \mathrm{~km}$ horizontal resolution. The model was run using WRF Single-Moment 3- class microphysics scheme, KainFritsch (new Eta) cumulus physics scheme, Yonsei University planetary boundary layer scheme, revised MM5 surface layer physics scheme, Rapid Radiative Transfer Model (RRTM) for long-wave and Dudhia scheme for short-wave scheme. The model was run for 24-h, 48-h, 72-h and 96-h using the National Centre for Environmental Prediction (NCEP) high-resolution Global Final (FNL) Analysis 6-hourly data using initial and lateral boundary conditions. The model simulated landfall position errors are found $53 \mathrm{~km}, 129 \mathrm{~km}, 119 \mathrm{~km}$ and $23 \mathrm{~km}$ and time errors are found $02 \mathrm{E}$, 06 D, 02 E and 00 for 96-h, 72-h, 48-h and 24-h model run respectively (E indicates Earlier and D indicates Delay). The minimum time and position error is found in 24-hrs simulation. The spatial distribution is captured by the model is almost appropriate but the computational station rainfall is found less than that of observed rainfall.
\end{abstract}

Keywords: Cyclonic disturbances, Weather Research and Forecasting, Model Simulated Rainfall, Bay of Bengal

\section{INTRODUCTION}

Bangladesh is a low-lying, riverine country located in South Asia with a largely marshy jungle coastline of $580 \mathrm{~km}$ on the northern littoral of the Bay of Bengal (Sarma et al. 2000). It is a land of natural calamities which is one of the principal barriers behind our socio-economic progress. Thus, cyclones also have severe socio-economic impact over this country. In the pre-monsoon and post-monsoon season cyclones formed over the Bay of Bengal and its causes damage and a lot of causalities (Balaguru et al. 2014; Akter and Tsuboki, 2014). Almost every year natural disasters take many valuable lives and also create famine, poverty, unemployment, disempowerment problems (Hoque et al. 2017).

The Indian subcontinent with a long coastline has experienced nearly $10 \%$ of the global tropical cyclones (De et al., 2005). Most of the tropical

Corresponding author: Sharmin Rahman

Email: sharmin.r.mithila@gmail.com

DOI: https://doi.org/10.3329/dujees.v10i1.56278 cyclones have their initial genesis over the Bay of Bengal and strike Bangladesh coast and the east coast of India. On an average, 5 to 6 tropical cyclones form every year, out of these 2 or 3 can be severe. The number of cyclones occur in the Bay of Bengal is higher than Arabian Sea. This is probably due to the fact that Sea Surface Temperature over the Bay of Bengal is higher than over the Arabian Sea (Sattar and Cheung, 2019).

Again Bangladesh has a subtropical monsoon climate characterized by wide seasonal variations in rainfall, moderately warm temperatures, and high humidity. There are four prominent seasons in a year namely; winter (December - February), pre-monsoon (March-May), monsoon (June-September) and post monsoon (October- November) (Hossain and Anam, 2012). Cyclones of severe intensity and frequency in the north Indian Ocean are bi-modal in character, shows a maximum peaking once from mid-April to mid-June and again from October to mid-December. Over the Bay of Bengal and the Arabian Sea, during the southwest monsoon season (June to September), the intense systems usually do not develop due to 
northward shift of the ITCZ over the land and high tropospheric wind shear (Singh et al., 2000).

Numerical Weather Prediction using WRF model is used in many developed countries like United States of America, Canada, Japan, United Kingdom etc. (Perez et al. 2013). The idea of Numerical Weather Prediction (NWP) was first introduced by Vilhelm Bjerknes in 1904. He showed in principle how the laws of physics could be used to develop a procedure for atmospheric prediction (Shuman, 1989). With the development of electronic computers, weather forecasting became one of the most important projects. In 1948, Charney established the meteorology group to find a better forecasting method using the computer (Charney et al. 1990). Numerical modeling studies of tropical cyclones are being continuously attempted since 1960s to understand the physical and dynamical mechanisms of tropical cyclone development and movement. Ooyama published the first successful numerical simulation of a tropical cyclone, showing other things that intensification of such storms indeed relies crucially on surface enthalpy fluxes (Ooyama, 1969). The developments during 1980s and 1990s were capable of more realistic simulation of convective heating and cumulus parameterization (Sellers et al. 1997). In the present day, with the development of very powerful computing system, some high resolution three dimensional asymmetric numerical models have been developed.

Tropical cyclone can neither be destroyed nor be prevented, but the damages can be minimized by proper management practices which may include early warning, preparedness, rescue operation, rehabilitation etc (Rogers and Tsirkunov, 2011). Time and location specific forecasting of tropical cyclone may reduce the damage and casualties of a cyclone. So WRF model based more studies are required in Bangladesh to analyze the features and criteria of the tropical cyclone. This research will help to evaluate the performance of the WRF model based simulation of tropical cyclonic Storm (Table 1). Here the cyclonic storm 'Roanu' was selected that moved toward Bay of Bengal on 18 may to 22 May, 2016 (Maw and Min, 2017).

\section{MATERIALS AND METHODS}

\section{Model Data}

Numerous types of weather data are collected by various weather observatories and meteorological departments around the world and then reanalyzed by different simulation models and NWP (Reddy and Babu, 2017). Here The National Centre for Environmental Prediction (NCEP) and high-resolution Global Final Analysis (FNL) data on grids were taken as the initial and lateral boundary condition. The analyses are available on the surface at 26 mandatory levels from 1000 millibars to 10 millibars. Others important parameters for the research were surface pressure, sea level pressure, geopotential height, temperature, sea surface temperature, soil values, ice cover, relative humidity, wind, vertical motion, vorticity and ozone (Ali et al. 2007). The observed rainfall data of Bangladesh Meteorological Department (BMD) were used to compare the model predicted rainfall.

Table 1: Overview of the Configurations for WRF Model (based on Kain et al. 2006)

\begin{tabular}{|c|c|}
\hline \multicolumn{2}{|l|}{ Dynamics } \\
\hline WRF core & ARW \\
\hline Data & NCEP-FNL \\
\hline Interval & $1-\mathrm{h}$ \\
\hline Number of domain & 1 \\
\hline $\begin{array}{l}\text { Central point of the } \\
\text { domain }\end{array}$ & $23^{\circ} \mathrm{N}, 90^{\circ} \mathrm{E}$ \\
\hline $\begin{array}{l}\text { Horizontal grid } \\
\text { distance }\end{array}$ & $20 \mathrm{~km}$ \\
\hline Integration time step & $50 \mathrm{~s}$ \\
\hline Number of grid points & $\begin{array}{l}\text { X-direction } 167 \text { points, Y- } \\
\text { direction, } 223 \text { points }\end{array}$ \\
\hline Covered area & $7^{\circ}-27^{\circ} \mathrm{N}$ and $78^{\circ}-98^{\circ} \mathrm{E}$ \\
\hline Map projection & Mercator \\
\hline Vertical coordinate & Pressure coordinate \\
\hline $\begin{array}{l}\text { Time integration } \\
\text { scheme }\end{array}$ & $3^{\text {rd }}$ order Runge-Kutta \\
\hline $\begin{array}{l}\text { Spatial differencing } \\
\text { scheme }\end{array}$ & $6^{\text {th }}$ order centered differencing \\
\hline \multicolumn{2}{|l|}{ Physics } \\
\hline Microphysics & Single-moment 3-class scheme \\
\hline PBL Parameterization & Yonsei University (YSU) scheme \\
\hline Surface layer physics & Revised MM5 scheme \\
\hline Land surface model & Unified Noah LSM \\
\hline Short wave radiation & Dudhia scheme \\
\hline Long wave radiation & RRTM scheme \\
\hline $\begin{array}{l}\text { Cumulus } \\
\text { Parameterization }\end{array}$ & $\begin{array}{l}\text { 1.Kain-Fritsch (new Eta) Scheme } \\
\text { 2.Betts-Miller-Janjic Scheme } \\
\text { 3. Grell-Freitas ensemble Scheme }\end{array}$ \\
\hline
\end{tabular}




\section{Model Setup and Methodology}

The ARW dynamics solver of WRF has been used as the principal modeling tool. Global Final Analysis (FNL) data have been used as input to the WRF model (Lo et al., 2008). For case study, cyclone Roanu events of 18-22 May, 2016 have been selected. The model was run for 24-h, 48-h, 72-h, and 96-h advanced respectively. The model was configured on single domain with $20 \mathrm{~km}$ horizontal grid spacing. The domain has 167 and 223 grid points in the west-east and north-south directions respectively. The domain was configured to have the same vertical structure of 38 unequally spaced sigma levels. The center ( $23 \mathrm{~N}, 90 \mathrm{E})$ of the domain was taken over Bangladesh. The physical parameterization schemes used in this study are SingleMoment 3-class microphysics scheme, Kain-Fritsch (new Eta) scheme for cumulus parameterization, Yonsei University scheme (YSU) for planetary boundary layer. Betts-Miller-Janjic Scheme and GrellFreitas ensemble Scheme are also used for comparison to get better approximation.

The model performance was evaluated by examining the different predicted parameters like mean sea level pressure, lower and upper level wind patterns, horizontal and vertical profile of relative humidity, vertical wind shear of the u-component of wind, lower and upper level relative vorticity, temperature, vertical distribution of velocity components, rainfall etc.

\section{Description of the Selected Cyclone Case Roanu}

The cyclonic storm 'Roanu' has been named by Maldives. "Roanu" means "coir rope" in Maldivian

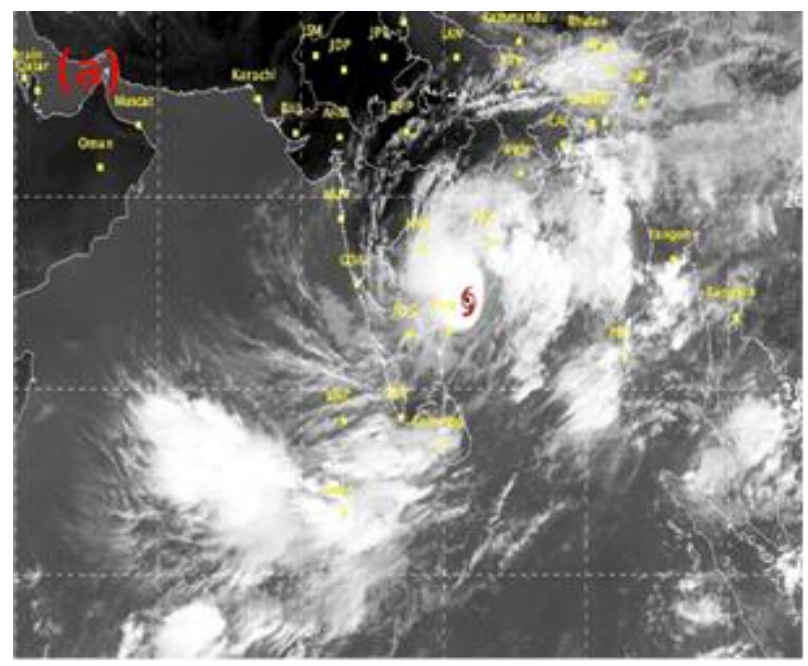

(Dhivehi). Cyclonic storm 'Roanu' was a relatively weak Tropical Cyclone (TC) that caused severe flooding in Sri Lanka and Bangladesh during its life period (Rahman et al., 2020). Bangladesh Meteorological Department (BMD) and India Meteorological Department (IMD) classified it as a depression on $17^{\text {th }}$ May (Hossain et al., 2017). Late the same day, the Joint Typhoon Warning Center (JTWC) issued a tropical cyclone formation alert (TCFA), soon after which the JTWC upgraded the system to a tropical storm. It further moved nearly northwards, intensified into a deep depression (DD) and lay centered over west central and adjoining southwest Bay of Bengal near latitude $13.3^{\circ} \mathrm{N}$ and longitude $81.0^{\circ} \mathrm{E}$ at $0300 \mathrm{UTC}$ of $18^{\text {th }}$. It intensified into a cyclonic storm (CS) over west central Bay of Bengal and lay centered near latitude $15.10 \mathrm{~N}$ and longitude $81.40 \mathrm{E}$ with maximum sustained winds of 35 knots around the system center at 0000 UTC of $19^{\text {th }}$. On $19^{\text {th }}$ May, BMD and IMD reported that the system had reached to cyclonic storm intensity assigning the name 'Roanu' (Mandal et al., 2018). The system maintained its intensity of 45 knots and crossed Bangladesh coast near latitude $22.60 \mathrm{~N}$ and longitud91.60E, to the north of Chittagong around 1000 UTC of $21^{\text {st }}$ May as a CS. After landfall, the system started weakening due to land interactions. Continuing its east-northeastward journey, the CS gradually weakened into a DD over Mizoram at 1800 UTC of $21^{\text {st }}$, into a depression over Myanmar and adjoining Manipur at 0000 UTC of $22^{\text {nd }}$ and into a well-marked low pressure area over Myanmar and adjoining Nagaland \& Manipur at 0300 UTC of $22^{\text {nd }}$ May (Ali et al. 2020).

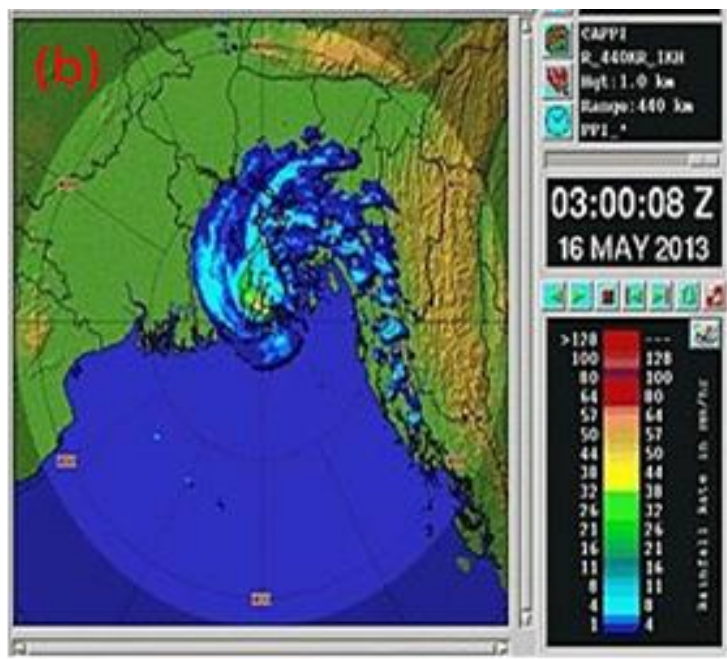

Figure 1 (a-b): (a) Insat-3D IR image and (b) Khepupara Doppler radar image of cyclone 'Roanu'. 


\section{RESULT AND DISCUSSIONS}

The simulated results and discussion of the cyclone Roanu are outlined in the following sections.

\section{Analysis of Mean Sea Level Pressure (MSLP)}

The formation of low pressure area is an important initial condition for possible weather disturbances which may intensify into a tropical cyclone when the favorable conditions prevail. The model derived mean sea level pressure $(\mathrm{hPa})$ of the cyclone Roanu valid at 1000 UTC of $21^{\text {st }}$ May, 2016 based on the initial condition of 0000 UTC of 18, 19, 20 and 21 May, 2016 are shown in Figure 2 (a-d) respectively. It is found that the center of the cyclone at 1000 UTC on $21^{\text {st }}$ May, 2016 is located at $22.5^{\circ} \mathrm{N}, 92.3^{\circ} \mathrm{E} ; 20.6^{\circ} \mathrm{N}, 90.3^{\circ} \mathrm{E}$; $22.1^{\circ} \mathrm{N}, 92.4^{\circ} \mathrm{E}$ and $22.6^{\circ} \mathrm{N}, 91.4^{\circ} \mathrm{E}$ respectively over the southeastern part of Bangladesh and adjoining area and the Mean Sea Level Pressure of the depression was nearly $953 \mathrm{hPa}, 945 \mathrm{hPa}, 976 \mathrm{hPa}$ and $985 \mathrm{hPa}$ based on $96,72,48$, and 24 hours advance model run. The lowest simulated central pressure of cyclonic storm Roanu is about $945 \mathrm{hPa}$.
Table 2: Central pressure analysis of $96 \mathrm{~h}, 72 \mathrm{~h}, 48 \mathrm{~h}$ and $24 \mathrm{~h}$ simulation

\begin{tabular}{|l|c|c|c|c|}
\hline Parameter & $\begin{array}{c}96 \text { hours } \\
(\mathrm{hPa})\end{array}$ & $\begin{array}{c}72 \text { hours } \\
(\mathrm{hPa})\end{array}$ & $\begin{array}{c}48 \text { hours } \\
(\mathrm{hPa})\end{array}$ & $\begin{array}{c}24 \text { hours } \\
(\mathrm{hPa})\end{array}$ \\
\hline Time & $21^{\text {st }}$ May, & $21^{\text {st }} \mathrm{May}$, & $21^{\text {st }}$ May, & $21^{\text {st }}$ May, \\
$2016 /$ & $2016 /$ & $2016 /$ & $2016 /$ \\
$1000 \mathrm{UTC}$ & $1000 \mathrm{UTC}$ & $1000 \mathrm{UTC}$ & $1000 \mathrm{UTC}$ \\
\hline $\begin{array}{l}\text { Central } \\
\text { Pressure }\end{array}$ & 953 & 945 & 976 & 985 \\
\hline
\end{tabular}

\section{Wind Flow Analysis at 850 hPa level}

The horizontal distribution of wind flow $\left(m s^{-1}\right)$ at $850 \mathrm{hPa}$ level of tropical cyclone Roanu at 1000 UTC of $21^{\text {st }}$ May, 2016 for 96-h, 72-h, 48-h and 24-h model run are represented in Figure 3 (a-d). Strong cyclonic circulation is found in every stage of wind distribution at this level that is the evident for the inflow of wind in lower level. It is also found that a cyclonic circulation lies over the coast of southeastern part of Bangladesh and adjoining area having its center at $22.5^{\circ} \mathrm{N}, 92.3^{\circ} \mathrm{E} ; 20.5^{\circ} \mathrm{N}, 91^{\circ} \mathrm{E} ; 22^{\circ} \mathrm{N}$, $92.4^{\circ} \mathrm{E}$ and $22.6^{\circ} \mathrm{N}, 91.5^{\circ}$ Eat $850 \mathrm{hPa}$ level wind.
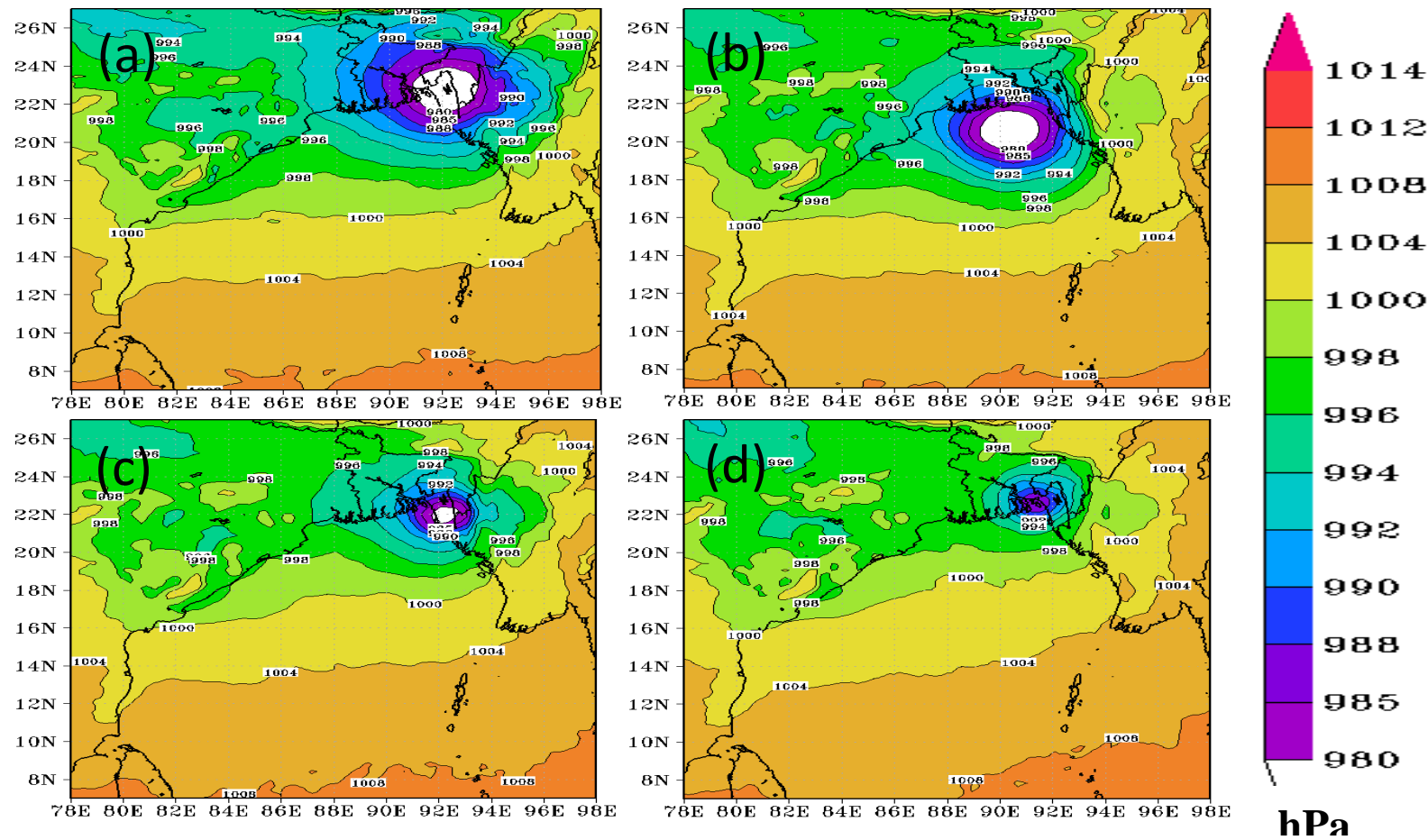

Figure 2 (a-d): The distribution of MSLP (hPa) analysis valid for 1000 UTC of $21^{\text {st }}$ May, 2016 and based on (a)96 hours(b) 72 hours(c) 48 hoursand (d)24 hours model run respectively. 

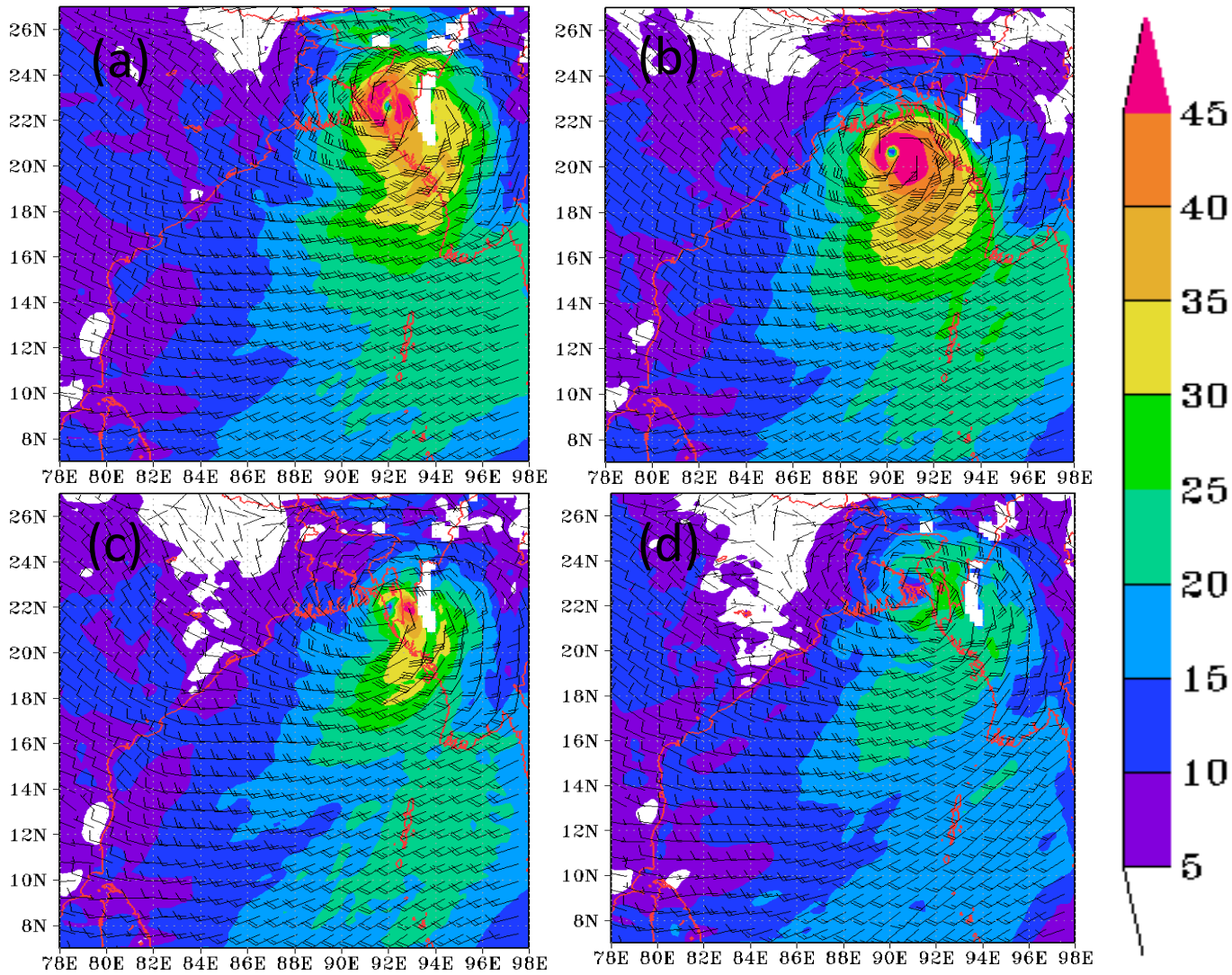

$m s^{-1}$

Figure 3 (a-d): Wind flow $\left(m s^{-1}\right)$ at $850 \mathrm{hPa}$ level valid for $1000 \mathrm{UTC}$ of $21^{\text {st }}$ May, 2016 and based on (a) 96-h (b) 72-h (c) 48-h and (d) 24-h model run respectively.
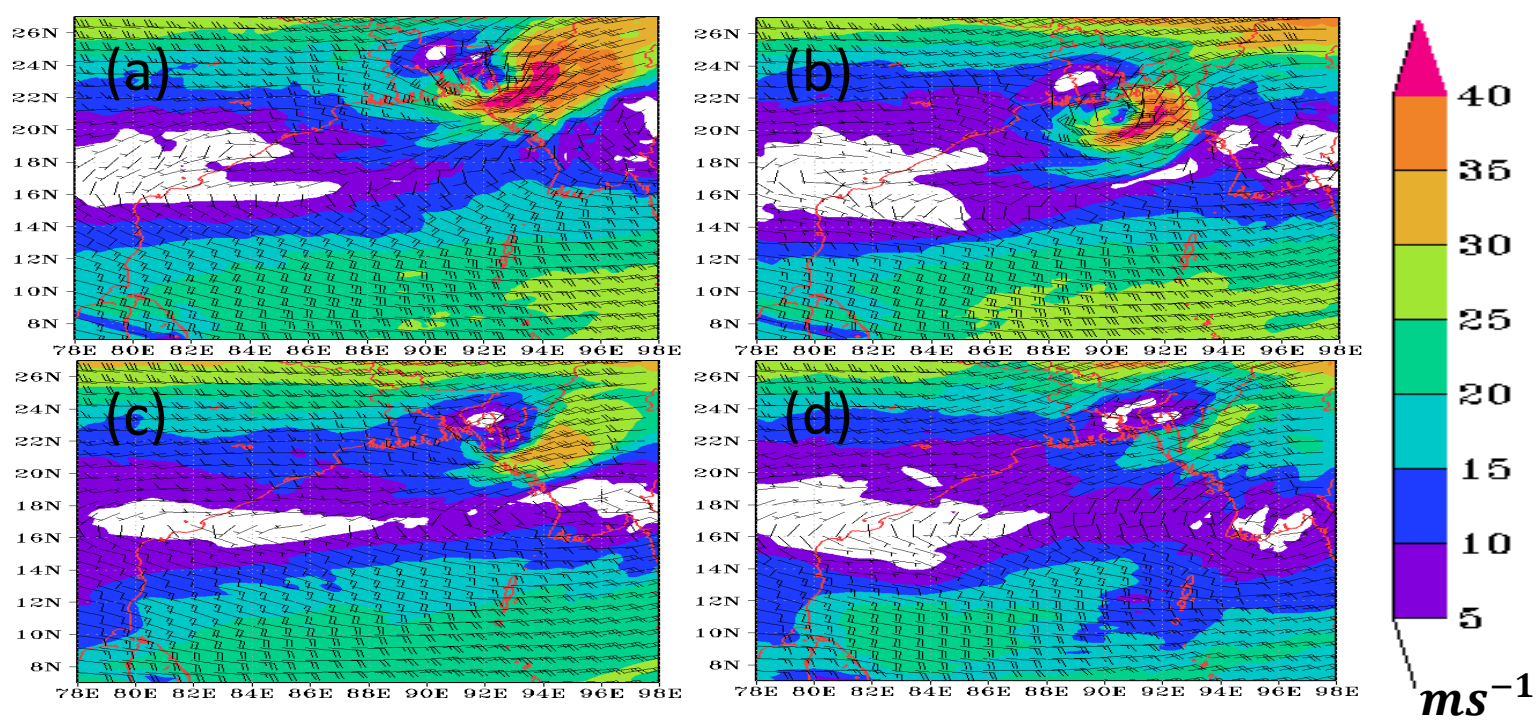

Figure 4 (a-d): Wind flow $\left(m s^{-1}\right)$ at $200 \mathrm{hPa}$ level valid for 1000 UTC of $21^{\text {st }}$ May, 2016 and based on (a) 96-h (b) 72-h (c) 48-h and (d) 24-h model run respectively.

\section{Wind Flow Analysis at 200 hPa level}

The horizontal distribution of wind flow $\left(m s^{-1}\right)$ at $200 \mathrm{hPa}$ level of tropical cyclone Roanu at 1000
UTC of $21^{\text {st }}$ May, 2016 for 96-h, 72-h, 48-h and 24-h model run are represented in Figure 4 (a-d). 
Relative Humidity at 850 hPa Level and Its Vertical Cross-Section

The distribution of relative humidity for the tropical cyclone Roanu at $850 \mathrm{hPa}$ level valid at 1000 UTC of $21^{\text {st }}$ May, 2016 for 96-h, 72-h, 48-h and 24-h model. It is seen that the system is associated with high relative humidity (above $80 \%$ ) that moves continuously to the northeastern direction. The high amount of relative humidity is an important environmental variable associated with cloud and rain formation (Fan et al., 2007). From Figure 5 (a-d) it is found that there is strong southwesterly flow that carries a huge amount moisture with a value of around (80-100) \% over southern part of Bangladesh and adjoining areas.
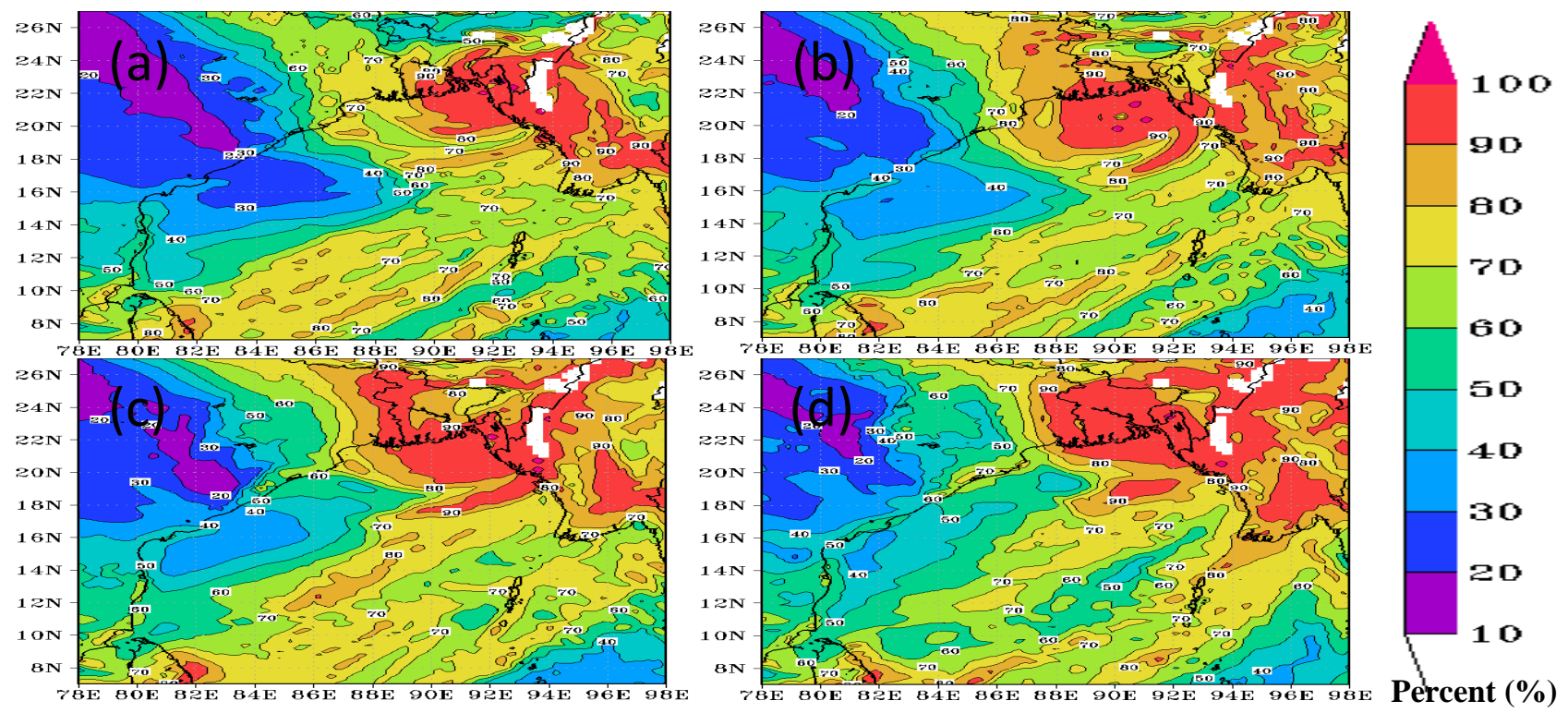

Figure 5 (a-d):Relative humidity (\%) at $850 \mathrm{hPa}$ level valid for 1000 UTC of 21 ${ }^{\text {st }}$ May, 2016 and based on (a) 96-h (b) 72-h (c) 48-h and (d) 24-h model run respectively
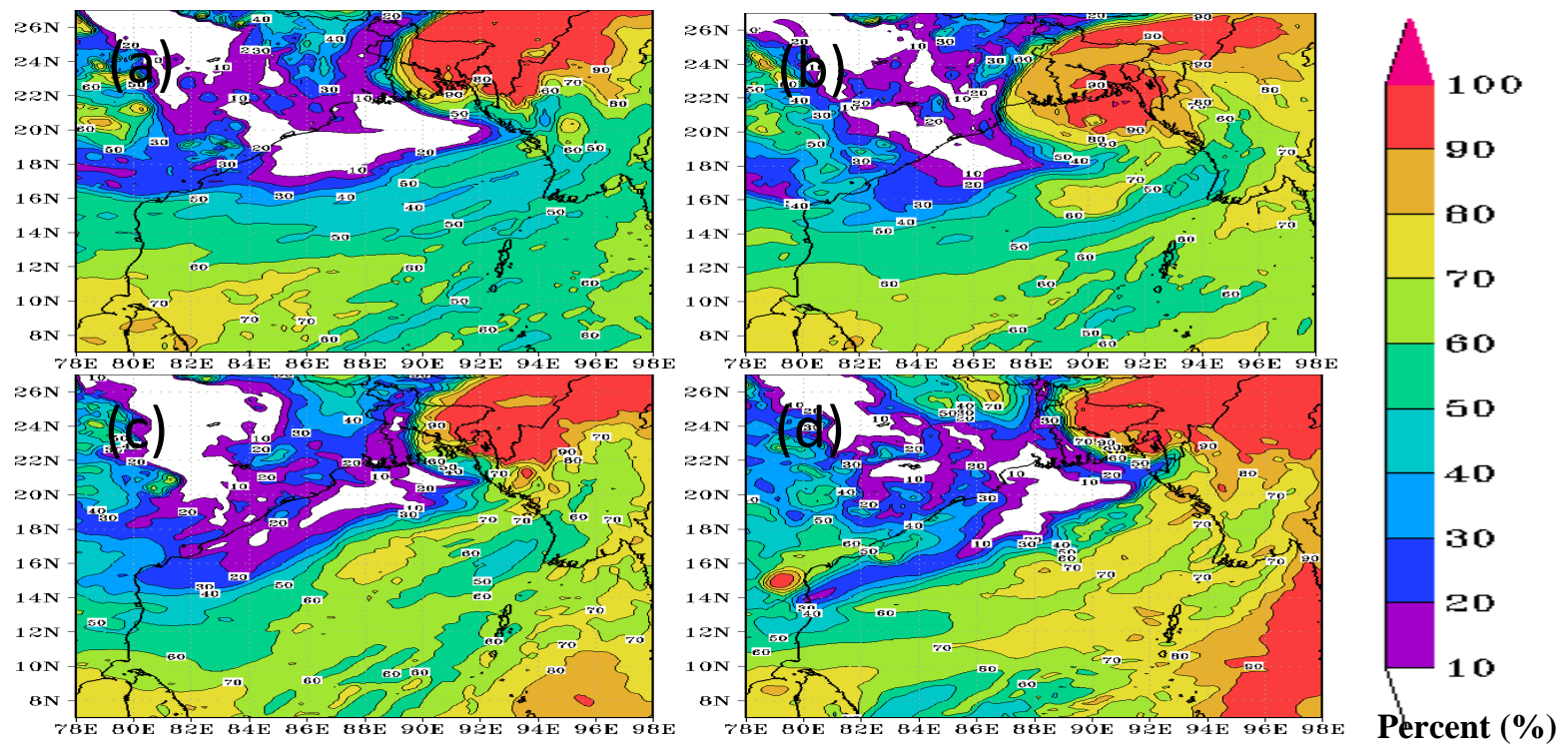

Figure 6 (a-d):Relative humidity (\%) at $500 \mathrm{hPa}$ level valid for $1000 \mathrm{UTC}$ of $21^{\text {st }}$ May, 2016 and based on (a) 96-h (b) 72-h (c) 48-h and (d) 24-h model run respectively 


\section{Analysis of Relative Humidity at 500 hPa level}

The distribution of relative humidity for the tropical cyclone Roanu at $500 \mathrm{hPa}$ level valid at 1000 UTC of $21^{\text {st }}$ May, 2016 for 96-h, 72-h, 48-h and 24-h model run are represented in Figure 6 (a-d) based on 18, 19, 20 and 21 May, 2016.
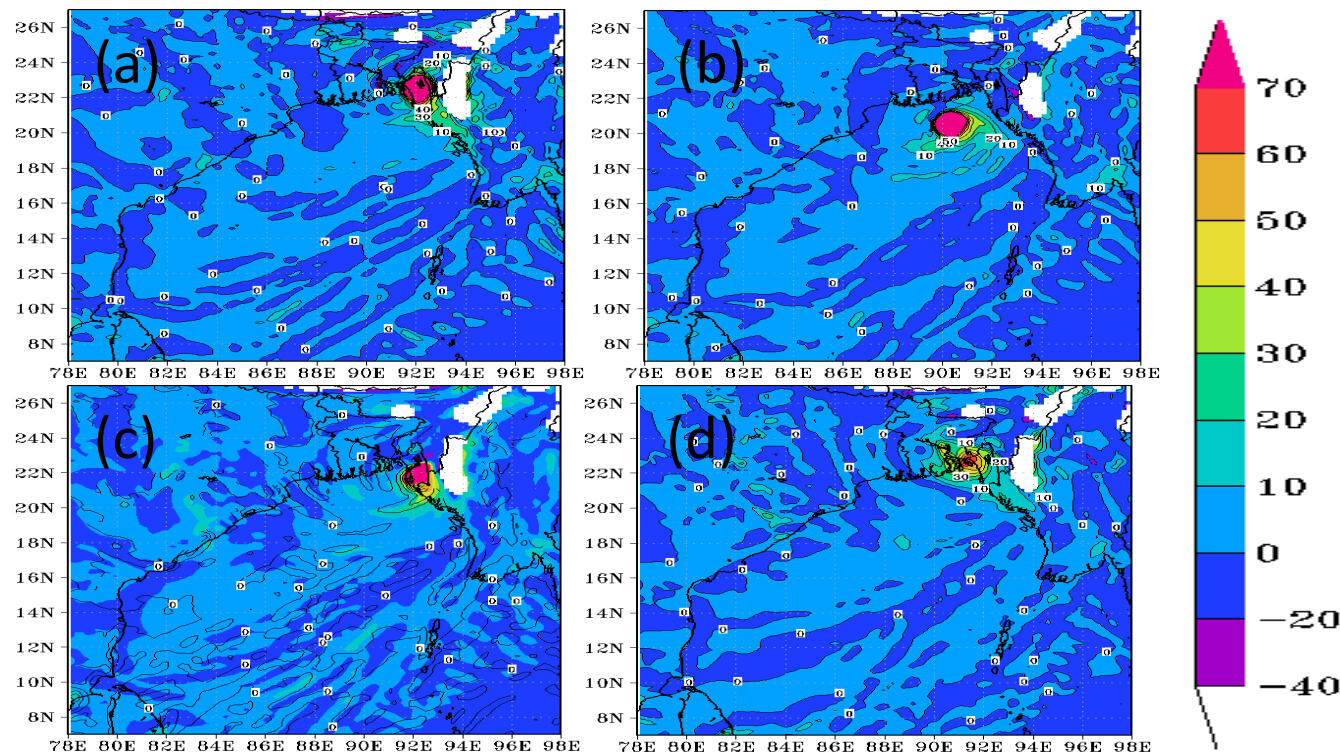

$e^{-5} s^{-1}$

Figure 7 (a-d): Vorticity at $850 \mathrm{hPa}$ level valid for 1000 UTC of $21^{\text {st }}$ May, 2016 and based on (a) 96-h, (b) 72-h, (c) 48-h and (d) 24-h model run respectively
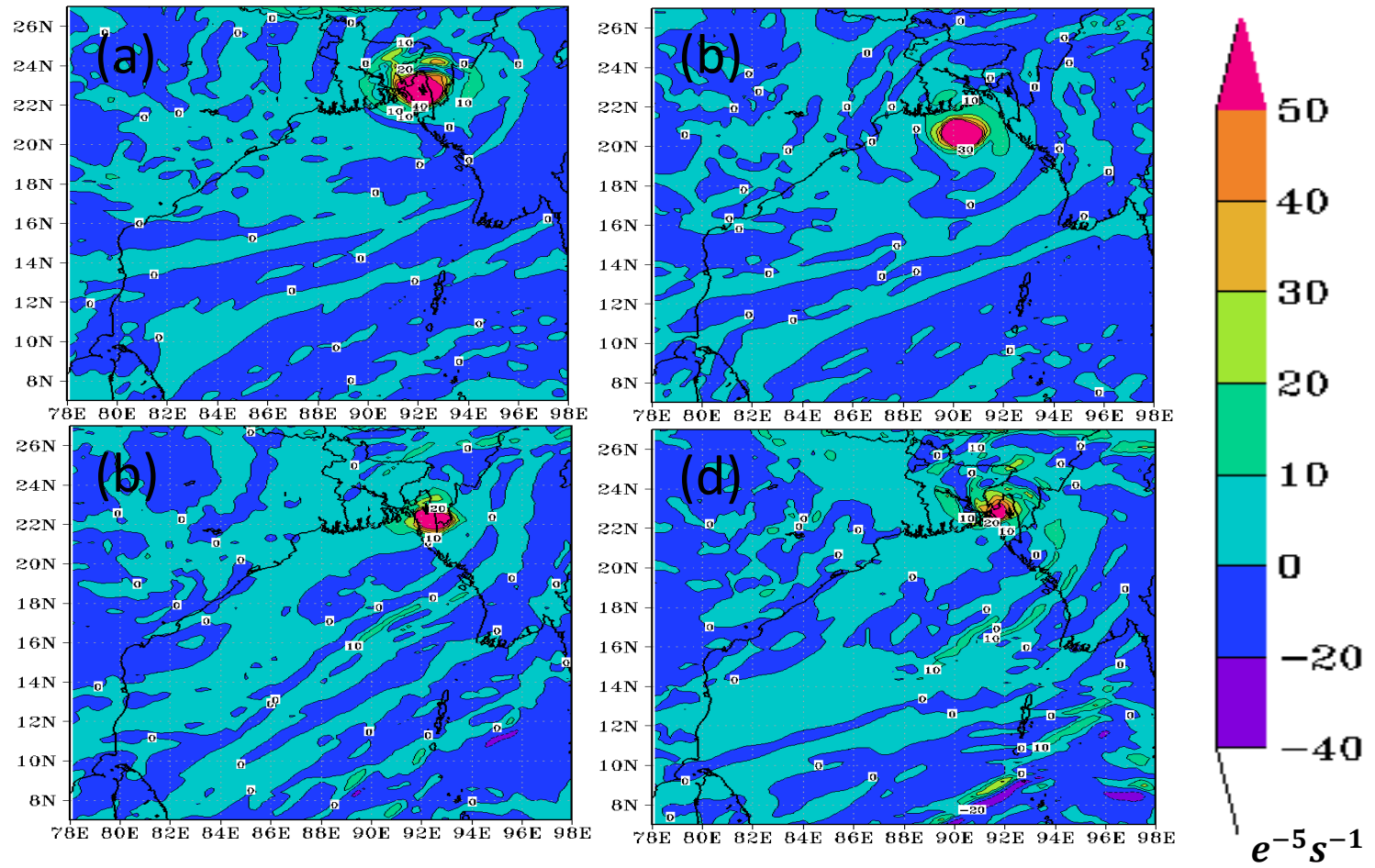

Figure 8 (a-d): Vorticity at $500 \mathrm{hPa}$ level valid for 1000 UTC of $21^{\text {st }}$ May, 2016 and based on (a) 96-h, (b) 72-h, (c) 48-h and (d) 24-h model run respectively 


\section{Vorticity Analysis at 500 hPa level}

The distribution of model simulated relative vorticity $\left(\times 10^{-5} S^{-1}\right)$ of the tropical cyclone Roanu at $500 \mathrm{hPa}$ level valid at1000 UTC of $21^{\text {st }}$ May, 2016 for 96-h, 72-h, 48-h and 24-h model run are represented in Figure 8 (a-d) respectively. From the analysis of relative vorticity at $500 \mathrm{hPa}$ level, it has been found that positive vorticity is at the surroundings of the system center. From the model simulation it is also found that the vorticity is generated $96 \mathrm{hrs}$ before landfall and it is always positive along the track up to $500 \mathrm{hPa}$ level.

\section{Analysis of Vertical Wind Shear}

The model simulated vertical wind shear $\left(\mathrm{ms}^{-1}\right)$ between $200 \mathrm{hPa}$ and $850 \mathrm{hPa}$ (u-component of wind) of tropical cyclone Roanu at 1000 UTC of $21^{\text {st }}$ May is shown in Figure 9 (a-d).
It is found from the vertical wind shear analysis that at the system center the value of the vertical wind shear is negative because at the system center the wind is in a calm condition. But at the surrounding areas of the system center, the value of the vertical wind shear starts to increase.

It is also found from the figures that the values of vertical wind shear decrease with the intensification of the system. At the peripheral region of the TC, thunder activities occur due to very strong vertical wind shear of about $20 \mathrm{~ms}^{-1}$ near landfall time, and this leads to the formation of heavy rainfall events over south and southeast coast of Bangladesh. The model simulated vertical windshear of some stations surrounding the systems are given in the Table 3 and the wind shear is found -2 to 32 .
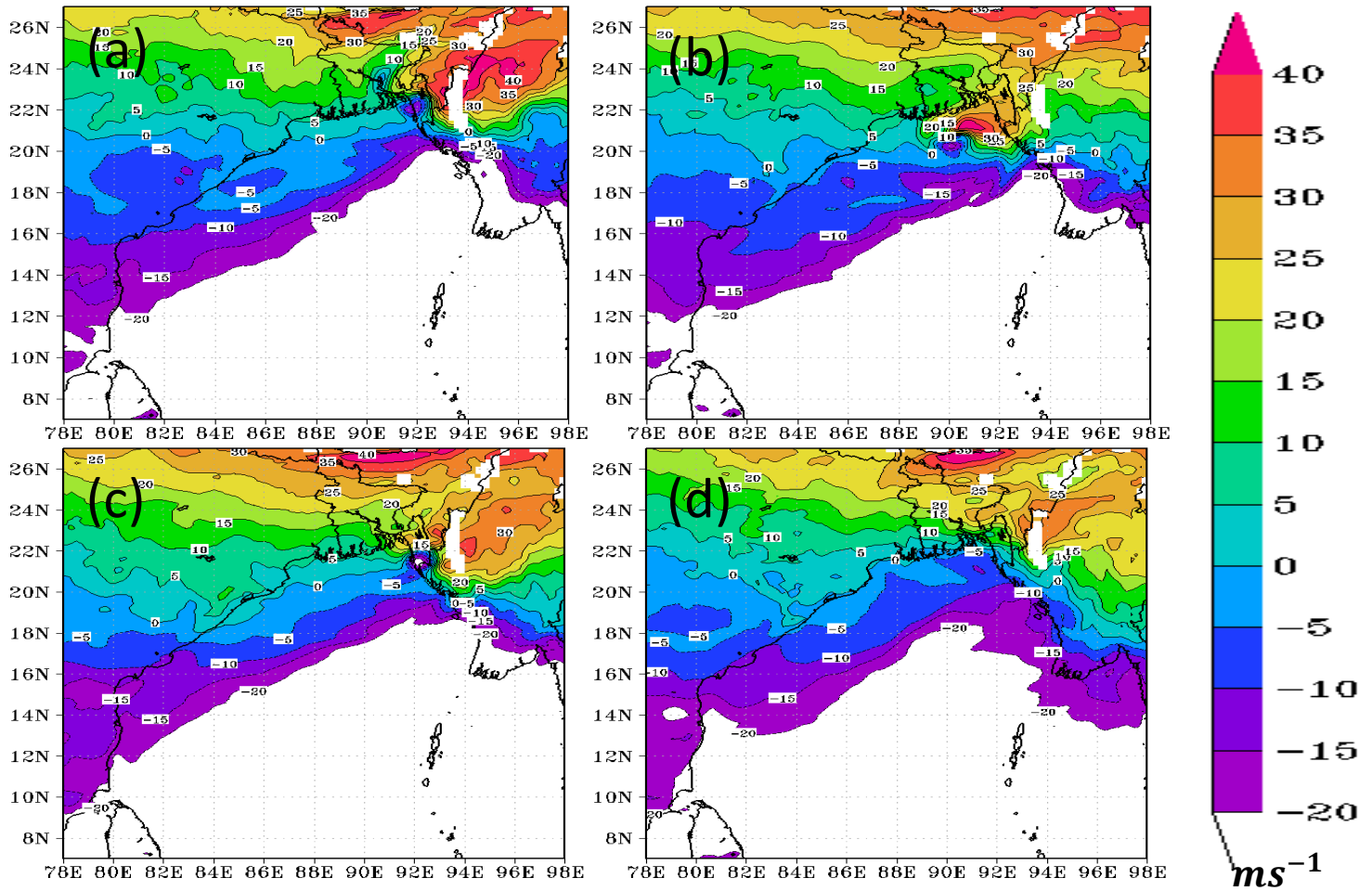

Figure 9 (a-d): Simulated wind shear $\left(\mathrm{ms}^{-1}\right)$ between 850 and $200 \mathrm{hPa}$ levels valid for $1000 \mathrm{UTC}$ of $21^{\text {st }}$ May, 2016 and based on (a) 96-h, (b) 72-h, (c) 48-h and (d) 24-h model run respectively. 
Table 3: The simulated vertical wind shear at the time of landfall of the cyclone Roanu

\begin{tabular}{|l|l|l|}
\hline Model run time(Hrs) & Station name & wind $\operatorname{shear}\left(\mathrm{ms}^{-1}\right)$ \\
\hline 96 & Chittagong- & -12 \\
& Noakhali- & 17 \\
& Comilla- & 20 \\
& Cox's Bazar- & -2 \\
\hline 72 & Chittagong- & 27 \\
& Noakhali- & 19 \\
& Comilla- & 18 \\
& Cox's Bazar- & 32 \\
\hline 48 & Chittagong- & 23 \\
& Noakhali- & 17 \\
& Comilla- & 16 \\
& Cox's Bazar- & -16 \\
\hline 24 & Chittagong- & 3 \\
& Noakhali- & 13 \\
& Comilla- & 25 \\
& Cox's Bazar- & -5 \\
\hline
\end{tabular}

\section{Analysis of Temperature at $850 \mathrm{hPa}$ level}

The model simulated temperature $\left({ }^{\circ} \mathrm{C}\right)$ at $850 \mathrm{hPa}$ of tropical cyclone Roanu valid at 1000 UTC of $21^{\text {st }}$ May, 2016for (a) 96-h, (b) 72-h, (c) 48-h and (d) 24hmodel run are shown in Figure 10 (a-d)respectively. From the analysis of temperature at $850 \mathrm{hPa}$ level, it is found that the temperature is about $(18-24)^{\circ} \mathrm{C}$ at the system center at the time of landfall. The model simulated temperature indicates that it was lower in southern part of Bangladesh as well as the other part of the country.

Table 4: The simulated temperature at the time of landfall of the cyclone Roanu at $850 \mathrm{hPa}$ level

\begin{tabular}{|l|l|l|}
\hline $\begin{array}{l}\text { Model run } \\
\text { time(Hrs) }\end{array}$ & Station name & Temperature $\left(/^{\circ} \mathrm{C}\right)$ \\
\hline 96 & Chittagong- & 21 \\
& Noakhali- & 20 \\
& Comilla- & 20 \\
& Cox's Bazar- & 20 \\
\hline 72 & Chittagong- & 22 \\
& Noakhali- & 22 \\
& Comilla- & 22 \\
& Cox's Bazar- & 21 \\
\hline 48 & Chittagong- & 20 \\
& Noakhali- & 20 \\
& Comilla- & 21 \\
& Cox's Bazar- & 21 \\
\hline 24 & Chittagong- & 19 \\
& Noakhali- & 19 \\
& Comilla- & 19 \\
& Cox's Bazar- & 18 \\
\hline
\end{tabular}
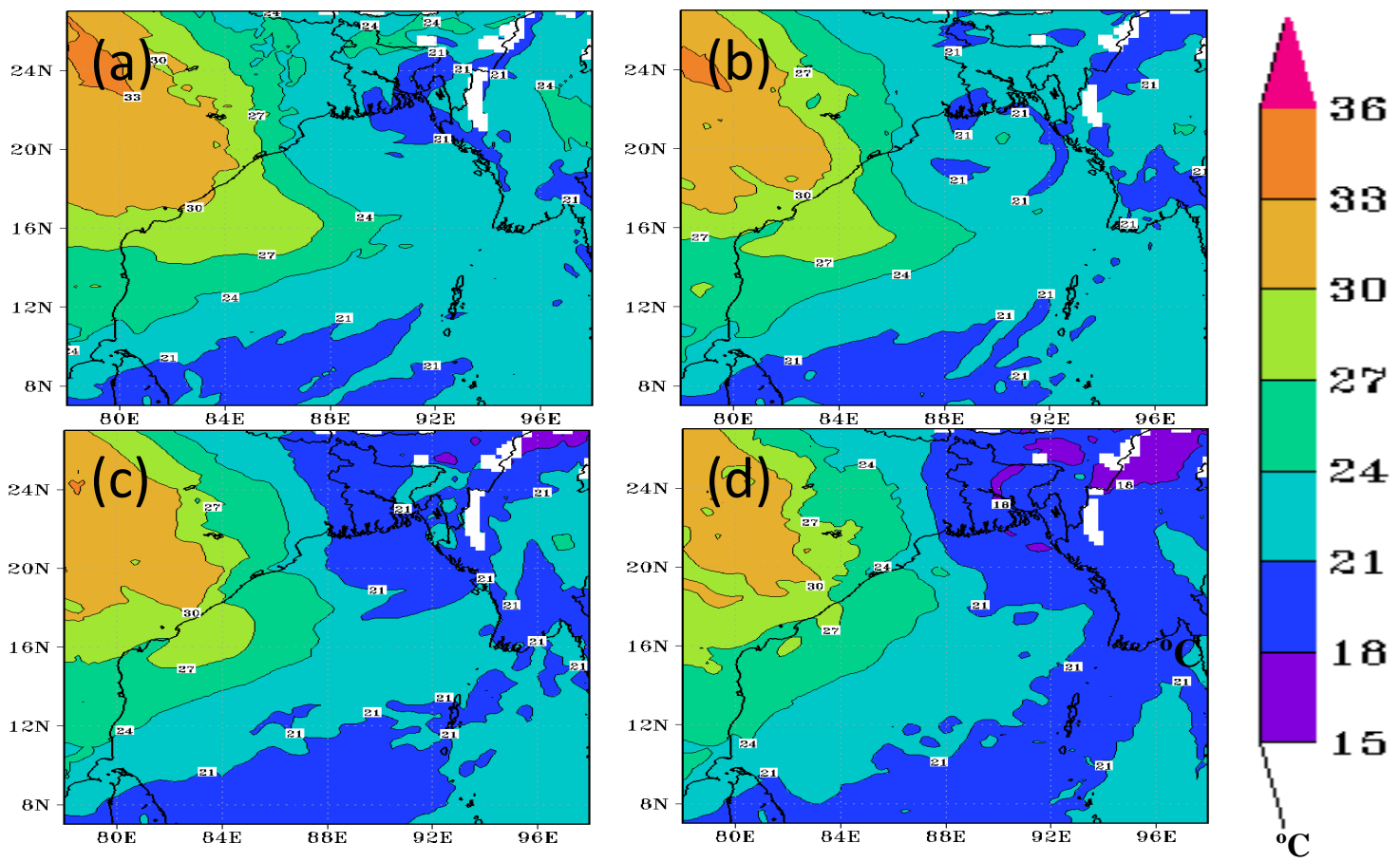

Figure 10 (a-d): Analysis of temperature in $\left({ }^{\circ} \mathrm{C}\right)$ at $850 \mathrm{hPa}$ level valid for $1000 \mathrm{UTC}$ of $21^{\text {st }}$ May, 2016 and based on (a) 96h, (b) 72-h, (c) 48-h and (d) 24-h model run respectively. 

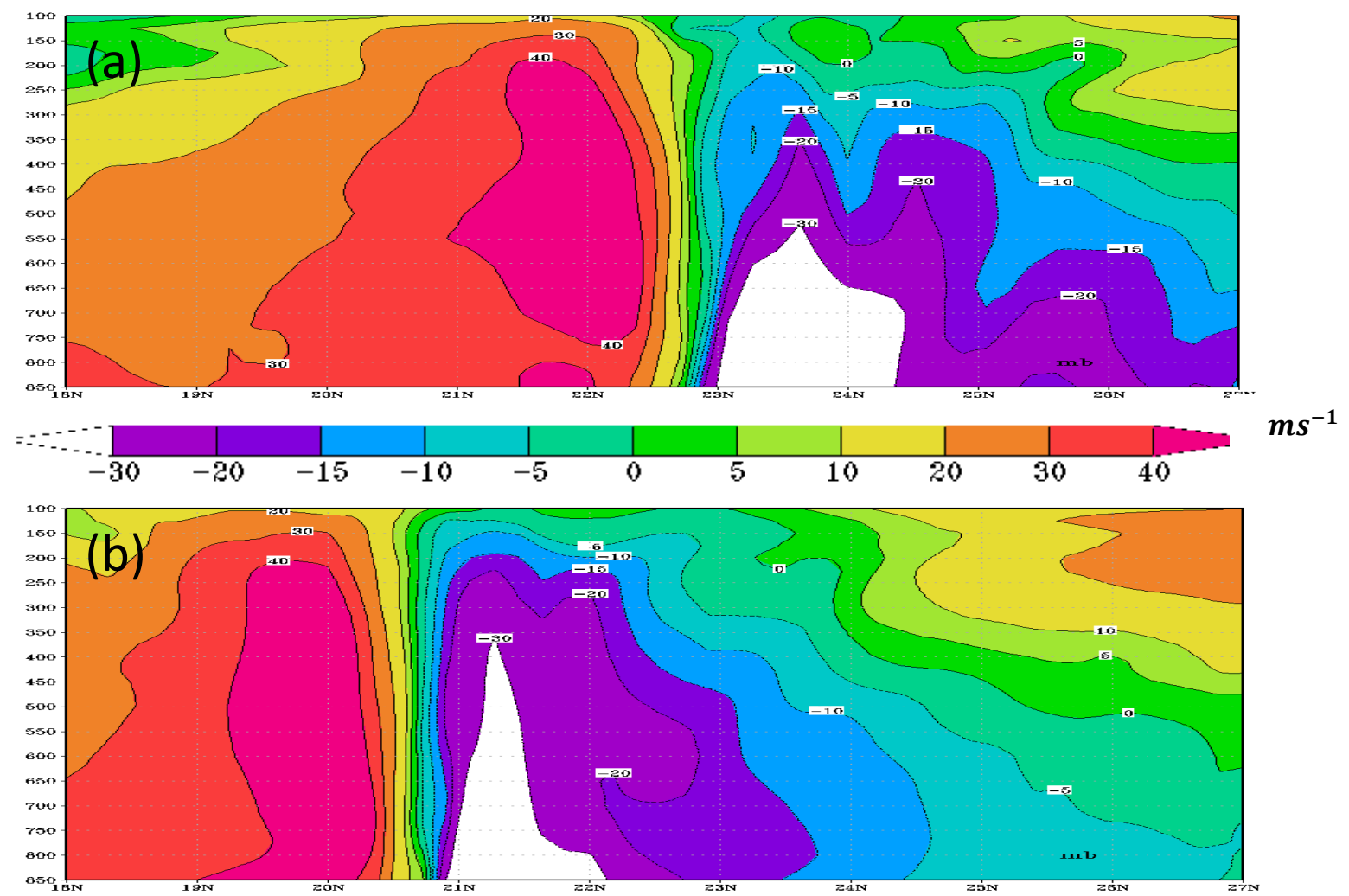

Figure 11 (a-b): Analysis of zonal wind valid for 1000 UTC of $21^{\text {st }}$ May, 2016 and based on (a) 96-h and (b) 72-h model run respectively.

\section{Analysis of Zonal Component of velocity}

Figures 11 (a-b) indicates the vertical distribution of zonal wind from $850-100 \mathrm{hPa}$ level along lon $92.3^{\circ}$ $\mathrm{E}$, lon $90.2^{\circ} \mathrm{E}$, lon $92.4^{\circ} \mathrm{E}$ and lon $91.4^{\circ} \mathrm{E}$ valid at 1000 UTC of $21^{\text {st }}$ May, 2016 for 96-h, 72-h respectively.

\section{Analysis of Meridional Component of velocity}

Figures $12(\mathrm{a}-\mathrm{b})$ indicates the vertical distribution of meridional wind along lat $22.5^{\circ} \mathrm{N}$, lat $20.5^{\circ} \mathrm{N}$, lat $22.0^{\circ} \mathrm{N}$ and lat $22.6^{\circ} \mathrm{N}$ valid at $1000 \mathrm{UTC}$ of $21^{\text {st }}$ May, 2016 for 96-h, 72-h run respectively.
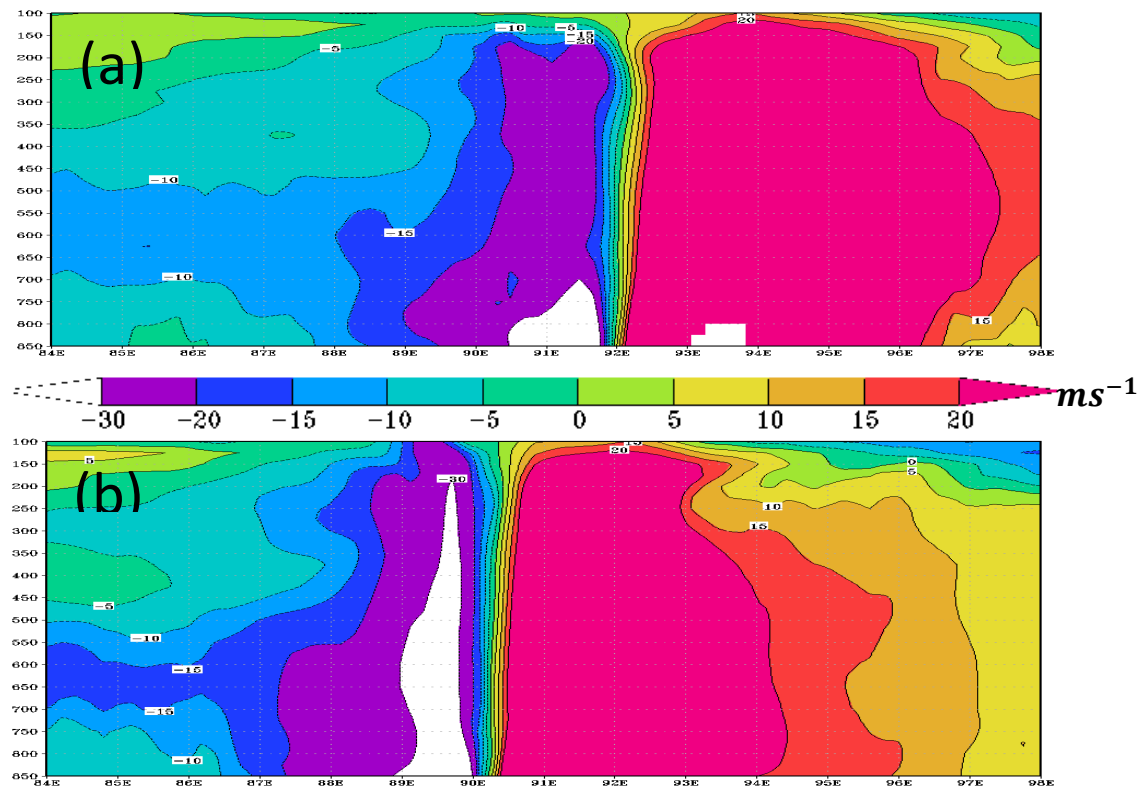

Figure 12 (a-b): Analysis of meridional wind valid for 1000 UTC of $21^{\text {st }}$ May, 2016 and based on(a) 96-h and (b) 72-h model run respectively. 


\section{Rainfall analysis}

The distribution of model simulated accumulated rainfall for the tropical cyclone Roanu valid at 1000

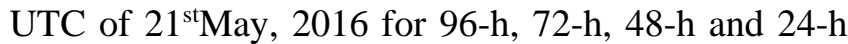
model run are represented in Figure 13 (a-d) based on
18, 19, 20 and 21May, 2016.It is seen that the model simulated rainfall is very heavy and it is about 225 $\mathrm{mm}$ over the southern part of Bangladesh and adjoining areas.
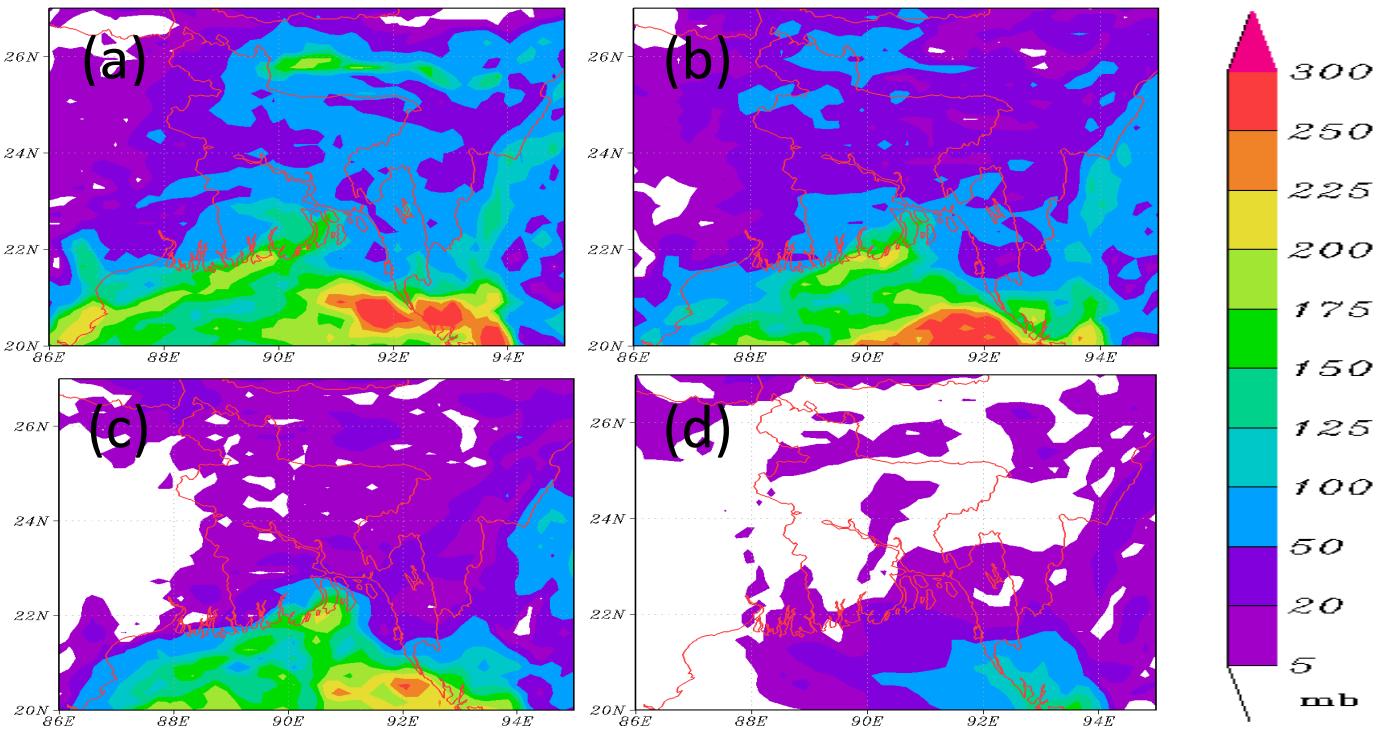

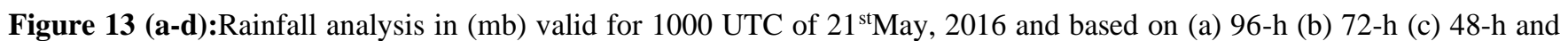
(d) 24-h model run respectively.

Table 5: Comparison of model simulated rainfall with observed rainfall of BMD

\begin{tabular}{|c|c|c|c|c|c|}
\hline $\begin{array}{l}\text { Model run time } \\
\text { (Hrs) }\end{array}$ & Station name & $\begin{array}{l}\text { Model simulated } \\
\text { Rainfall (mm) }\end{array}$ & $\begin{array}{l}\text { BMD observed } \\
\text { Rainfall }(\mathrm{mm})\end{array}$ & Errors (\%) & Average error (\%) \\
\hline 96 & $\begin{array}{l}\text { Chittagong- } \\
\text { Noakhali- } \\
\text { Comilla- } \\
\text { Cox’s Bazar- } \\
\text { Khepupara- } \\
\text { Barisal- } \\
\text { Patuakhali- } \\
\text { Hatiya- } \\
\text { Sandwip- } \\
\text { Sitakunda- } \\
\text { Bhola- }\end{array}$ & $\begin{array}{l}133 \\
197 \\
85 \\
109 \\
416 \\
269 \\
272 \\
307 \\
245 \\
195 \\
221 \\
\end{array}$ & $\begin{array}{l}128 \\
273 \\
214 \\
240 \\
428 \\
292 \\
312 \\
241 \\
220 \\
209 \\
283 \\
\end{array}$ & $\begin{array}{l}4 \\
28 \\
60 \\
55 \\
3 \\
8 \\
13 \\
27 \\
11 \\
7 \\
22 \\
\end{array}$ & 22 \\
\hline 72 & $\begin{array}{l}\text { Chittagong- } \\
\text { Noakhali- } \\
\text { Comilla- } \\
\text { Cox's Bazar- } \\
\text { Khepupara- } \\
\text { Barisal- } \\
\text { Patuakhali- } \\
\text { Hatiya- } \\
\text { Sandwip- } \\
\text { Sitakunda- } \\
\text { Bhola- }\end{array}$ & $\begin{array}{l}227 \\
124 \\
58 \\
155 \\
242 \\
60 \\
201 \\
197 \\
164 \\
161 \\
193\end{array}$ & $\begin{array}{l}127 \\
219 \\
212 \\
238 \\
405 \\
286 \\
306 \\
216 \\
135 \\
143 \\
275 \\
\end{array}$ & $\begin{array}{l}79 \\
43 \\
73 \\
35 \\
40 \\
79 \\
34 \\
9 \\
21 \\
13 \\
30\end{array}$ & 41 \\
\hline 48 & Chittagong- & 152 & 93 & 63 & \\
\hline
\end{tabular}




\begin{tabular}{|c|c|c|c|c|c|}
\hline & $\begin{array}{l}\text { Noakhali- } \\
\text { Comilla- } \\
\text { Cox's Bazar- } \\
\text { Khepupara- } \\
\text { Barisal- } \\
\text { Patuakhali- } \\
\text { Hatiya- } \\
\text { Sandwip- } \\
\text { Sitakunda- } \\
\text { Bhola- }\end{array}$ & $\begin{array}{l}56 \\
32 \\
78 \\
192 \\
67 \\
90 \\
141 \\
70 \\
90 \\
159\end{array}$ & $\begin{array}{l}157 \\
195 \\
162 \\
292 \\
256 \\
236 \\
122 \\
94 \\
117 \\
242\end{array}$ & $\begin{array}{l}64 \\
84 \\
52 \\
34 \\
74 \\
62 \\
13 \\
26 \\
23 \\
34\end{array}$ & 48 \\
\hline 24 & $\begin{array}{l}\text { Chittagong- } \\
\text { Noakhali- } \\
\text { Comilla- } \\
\text { Cox's Bazar- } \\
\text { Khepupara- } \\
\text { Barisal- } \\
\text { Patuakhali- } \\
\text { Hatiya- } \\
\text { Sandwip- } \\
\text { Sitakunda- } \\
\text { Bhola- }\end{array}$ & $\begin{array}{l}15 \\
28 \\
32 \\
45 \\
35 \\
101 \\
192 \\
49 \\
17 \\
16 \\
39\end{array}$ & $\begin{array}{l}60 \\
66 \\
110 \\
69 \\
112 \\
98 \\
61 \\
52 \\
53 \\
68 \\
73\end{array}$ & $\begin{array}{l}75 \\
58 \\
71 \\
35 \\
69 \\
3 \\
215 \\
6 \\
68 \\
76 \\
68\end{array}$ & 68 \\
\hline
\end{tabular}
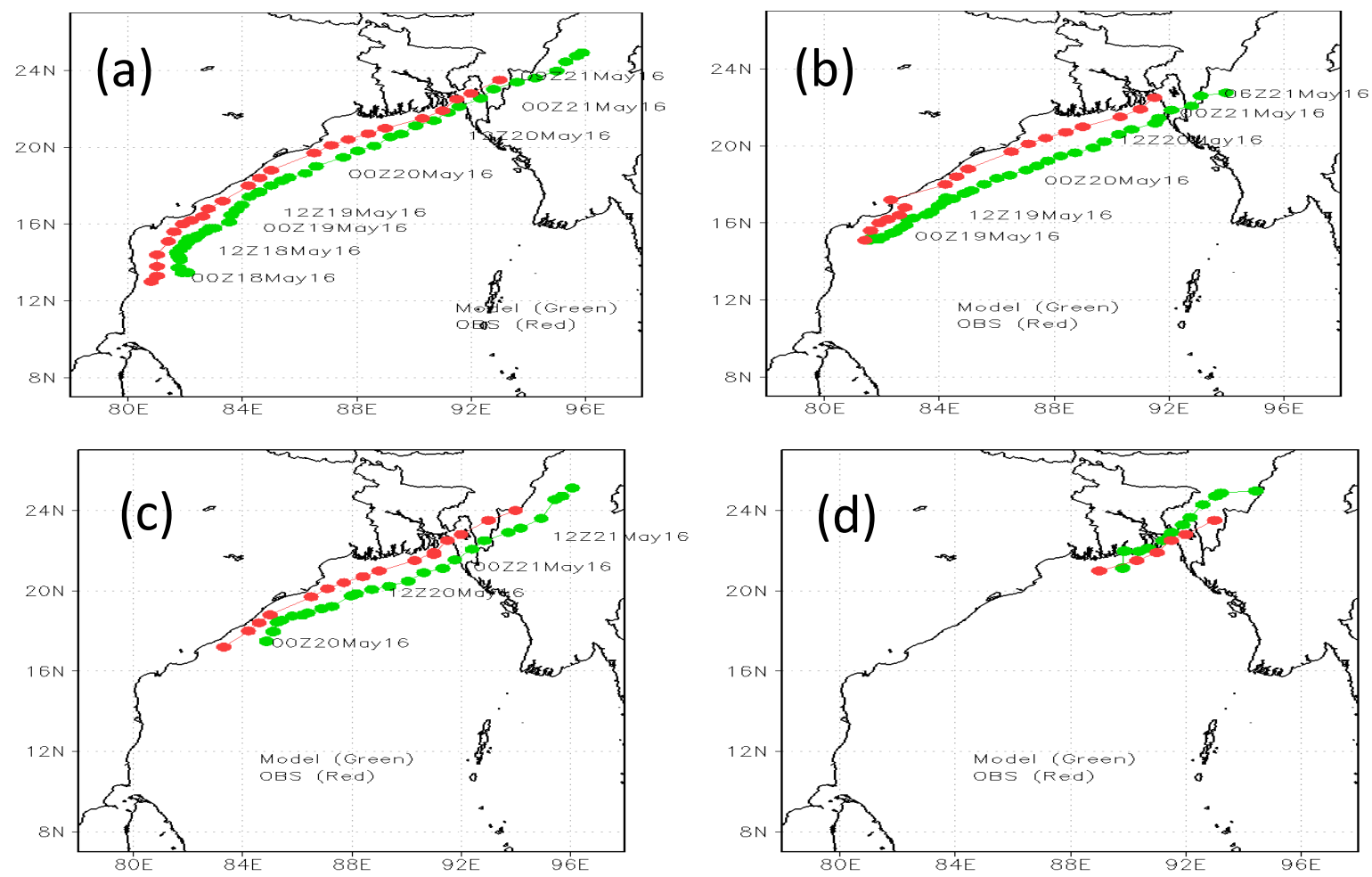

Figure 14 (a-d): The 96, 72, 48 and 24 hrs model predicted track (green) and observed track (red) beginning from (a) $18^{\text {th }}$ May, (b) $19^{\text {th }}$ May, (c) $20^{\text {th }}$ May and (d) $21^{\text {th }}$ May, 2016 respectively. 
Table 6: Landfall Position and Time Error of the Cyclone Roanu

\begin{tabular}{|c|c|c|c|c|c|c|c|}
\hline \multirow{2}{*}{$\begin{array}{l}\text { Base } \\
\text { Date/Time } \\
\text { (UTC) }\end{array}$} & \multirow{2}{*}{$\begin{array}{l}\text { Forecast } \\
\text { Hours }\end{array}$} & \multicolumn{2}{|l|}{ Landfall Forecast } & \multicolumn{2}{|l|}{ Actual Forecast } & \multicolumn{2}{|l|}{ Error } \\
\hline & & \begin{tabular}{|l|} 
Position \\
N/Lon ${ }^{\circ}$ E)
\end{tabular} & Time & \begin{tabular}{|ll} 
Position & Lat $^{\circ}$ \\
N/Lon & \\
\end{tabular} & Time & \begin{tabular}{|l}
$\begin{array}{l}\text { Distance } \\
(\mathrm{km})\end{array}$ \\
\end{tabular} & $\begin{array}{l}\text { Time } \\
\text { (hrs) }\end{array}$ \\
\hline $18 / 0000$ & 96 & $22.1 / 91.5$ & $\begin{array}{l}21^{\text {st }} \text { May/ } \\
0800 \text { UTC }\end{array}$ & $22.6 / 91.6$ & $\begin{array}{l}21^{\text {st }} \text { May/ } \\
1000 \text { (UTC) }\end{array}$ & 53 & $02 \mathrm{E}$ \\
\hline $19 / 0000$ & 72 & 21.4/91.6 & $\begin{array}{l}21^{\text {st }} \text { May/ } \\
1600 \text { (UTC) }\end{array}$ & -do- & -do- & 129 & 06D \\
\hline $20 / 0000$ & 48 & $21.5 / 91.7$ & $\begin{array}{l}21^{\text {st }} \text { May/ } \\
0800 \text { (UTC) }\end{array}$ & -do- & -do- & 119 & $02 \mathrm{E}$ \\
\hline $21 / 0000$ & 24 & $22.6 / 91.3$ & $\begin{array}{l}21^{\text {st }} \text { May/ } \\
1000(\text { UTC) }\end{array}$ & -do- & -do- & 23 & same \\
\hline
\end{tabular}

Track and Landfall Forecast Errors of Cyclone Roanu

The model simulated and observed track of tropical cyclone Roanu valid at 1000 UTC of $21^{\text {th }}$ May, 2016for (a) 96-h, (b) 72-h, (c) 48-h and (d) 24hmodel run based on the initial condition of 0000 UTC of 18, 19, 20 and 21 May, 2016 are shown in Figure 14 (a-d)respectively. The model predicted track (green) shows that the path taken by the cyclone Roanu is a little bit east with the comparison of observed track (red).

The landfall position and time errors of the cyclone Roanu are investigated for evaluating the WRF model performances (Basnayake et al., 2010). The result shows that $24 \mathrm{hrs}$ predictions exhibit low landfall position errors whereas 48, 72 and $96 \mathrm{hrs}$ predictions have comparatively high landfall position errors. The errors of are shown in Table 6.

\section{CONCLUSION}

On the basis of the research the following conclusions can be drawn:

- The model simulated central pressures of cyclonic storm Roanu are nearly $953 \mathrm{hPa}, 945 \mathrm{hPa}, 976$ $\mathrm{hPa}$ and $985 \mathrm{hPa}$ for 96-h, 72-h, 48-h and 24-h model run respectively at 1000 UTC of $21^{\text {st }}$ May, 2016. From the analysis it is found the lowest central pressure is $945 \mathrm{hPa}$ at the time of landfall.

- The convergence of strong southwesterly flow transports high amount of moisture (80-90) \% from the vast area of the Bay of Bengal towards the eastern and southeastern part of Bangladesh and neighborhood.
- The vertical profile of relative humidity along $23^{\circ} \mathrm{N}$ (position of Feni) shows that the humidity is (80-100) \% extended up to $300 \mathrm{hPa}$ level which enhances the supply of latent heat flux and which is very much supportive for convective activities in the peripheral region of the tropical cyclone Roanu.

- It is found that the model simulated vorticities at $850 \mathrm{hPa}$ and $500 \mathrm{hPa}$ level are of the order of $\left[(60-70) \times 10^{-5} s^{-1}\right.$ and $(40-50) \times$ $10^{-5} s^{-1}$ ]at the time of landfall 1000 UTC of $21^{\text {st }}$ May, 2016 which is very much supportive for the formation of deep convective clouds and the positive vorticity is the favorable condition for the intensification of the cyclone.

- The model simulated vertical wind shear $\left(u_{200^{-}}\right.$ $\left.u_{850}\right)$ is $>15 \mathrm{~ms}^{-1}$ near landfall time, and this leads rapids intensification of the cyclone and to the formation of heavy rainfall events over south and southeast coast of Bangladesh. Then the values of the windshear start to increase which is the indication of decaying of the system.

- The areas of Chittagong, Noakhali, Comilla, Cox's Bazar, Khepupara, Barisal, Patuakhali, Hatiya, Sandwip, Sitakunda, Bhola and neighborhoods where heavy to very heavy rainfall observed were characterized by the high amount of relative humidity and positive vorticity which were very favorable for the formation of deep convection and these parameters are very much supportive for moist air updrafts.

- The model simulated track and landfall are sensibly compared with the data observed by BMD. The model simulated landfall position 
errors are found $53 \mathrm{~km}, 129 \mathrm{~km}, 119 \mathrm{~km}$ and 23 $\mathrm{km}$ for $96-\mathrm{h}, 72-\mathrm{h}, 48-\mathrm{h}$ and $24-\mathrm{h}$ model run respectively. The model simulated landfall time errors are found $02 \mathrm{E}, 06 \mathrm{D}, 02 \mathrm{E}$ and same for 96-h, 72-h, 48-h and 24-h model run respectively (E indicates earlier and D indicates Delay). The minimum time and position error is found in 24hrs simulation.

Acknowledgement: Department of Physics, Mawlana Bhashani Science and Technology University, Storm Warning Center, Bangladesh Meteorological Department and Department of Physics, Jahangirnagar University are grateful acknowledged for the assistance throughout this research.

\section{REFERENCES}

Sarma, K.V.L.N.S., Ramana, M.V., Subrahmanyam, V., Krishna, K.S., Ramprasad, T. and Desa, M. (2000). Morphological Features in the Bay of Bengal.

Balaguru, K., Taraphdar, S., Leung, L.R. and Foltz, G.R. (2014). Increase in the Intensity of Post Monsoon Bay of Bengal Tropical Cyclones. Geophysical Research Letters, 41(10):3594-3601.

Akter, N. and Tsuboki, K. (2014). Role of Synoptic-Scale Forcing in Cyclogenesis over the Bay of Bengal. Climate Dynamics, 43(9-10):2651-2662.

Hoque, M.A.A., Phinn, S., Roelfsema, C. and Childs, I. (2017). Tropical Cyclone Disaster Management Using Remote Sensing and Spatial Analysis: A review. International Journal of Disaster Risk Reduction, 22:345-354.

De, U.S., Dube, R.K. and Rao, G.P. (2005). Extreme Weather Events over India in the Last 100 years. J. Ind. Geophys. Union, 9(3):173-187.

Sattar, A.M. and Cheung, K.K. (2019). Comparison between the Active tropical cyclone seasons over the Arabian Sea and Bay of Bengal. International Journal of Climatology, 39(14): 486-5502.

Hossain, M.M. and Anam, S. (2012). Identifying the Dependency Pattern of Daily Rainfall of Dhaka Station in Bangladesh Using Markov Chain and Logistic Regression Model.

Singh, O.P., Khan, T.A. and Rahman, M.S. (2000). Changes in the Frequency of Tropical Cyclones over the North Indian Ocean. Meteorology and Atmospheric Physics, 75(1): 11-20.

Perez, R., Lorenz, E., Pelland, S., Beauharnois, M., Van Knowe, G., Hemker Jr, K., Heinemann, D., Remund, J., Müller, S.C., Traunmüller, W. and Steinmauer, G.,
(2013). Comparison of Numerical Weather Prediction Solar Irradiance Forecasts in the US, Canada and Europe. Solar Energy, 94:305-326.

Shuman, F.G. (1989). History of Numerical Weather prediction at the National Meteorological Center. Weather and Forecasting, 4(3):286-296.

Charney, J.G., Fjörtoft, R. and Von Neumann, J. (1990). Numerical Integration of the Barotropic Vorticity equation. In the Atmosphere- A Challenge. American Meteorological Society, Boston, MA.

Ooyama, K. (1969). Numerical Simulation of the Life Cycle of Tropical Cyclones. Journal of the Atmospheric Sciences, 26(1):3-40.

Sellers, P.J., Dickinson, R.E., Randall, D.A., Betts, A.K., Hall, F.G., Berry, J.A., Collatz, G.J., Denning, A.S., Mooney, H.A., Nobre, C.A. and Sato, N. (1997). Modeling the Exchanges of Energy, Water, and Carbon between Continents and the Atmosphere. Science, 275 (5299):502-509.

Rogers, D. and Tsirkunov, V. (2011). Costs and Benefits of Early Warning Systems. Global Assessment Rep.

Maw, K.W. and Min, J. (2017). Impacts of Microphysics Schemes and Topography on the Prediction of the Heavy Rainfall in Western Myanmar Associated with Tropical Cyclone ROANU. Advances in Meteorology.

Reddy, P.C. and Babu, A.S. (2017). February. Survey on Weather Prediction Using Big Data Analytics. In 2017 Second International Conference on Electrical, Computer and Communication Technologies (ICECCT) pp. 1-6

Ali, M.M., Jagadeesh, P.V. and Jain, S. (2007). Effects of eddies on Bay of Bengal cyclone intensity. Eos, Transactions American Geophysical Union, 88(8): 9395.

Lo, J.C.F., Yang, Z.L. and Pielke Sr, R.A., 2008. Assessment of three dynamical climate downscaling methods using the Weather Research and Forecasting (WRF) model. Journal of Geophysical Research: Atmospheres, 113(D9).

Kain, J.S., Weiss, S.J., Levit, J.J., Baldwin, M.E. and Bright, D.R., 2006. Examination of convectionallowing configurations of the WRF model for the Prediction of Severe Convective Weather: The SPC/NSSL Spring Program 2004. Weather and Forecasting, 21(2):167-181.

Rahman, M.M., Paul, G.C. and Hoque, A. (2020). An Efficient Tide-Surge Interaction Model for the Coast of Bangladesh. China Ocean Engineering, 34(1):56-68. 
Hossain, M.A., Hasan, S.M.Q., Rashid, M.B., Mallik, M.A.K. and Islam, M.S. (2017). Storm Surge Simulation of Cyclone "Roanu" over Coastal Regions of Bangladesh Using MRI Storm Surge Model. DEWDROP, 3:46-54.

Mandal, S., Sil, S., Shee, A. and Venkatesan, R. (2018). Upper Ocean and subsurface variability in the Bay of Bengal during cyclone Roanu: a synergistic view using in situ and satellite observations. Pure and Applied Geophysics, 175(12), pp.4605-4624.

Ali, M.I., Saifullah, M., Imran, A., Syed, I.M. and Mallik, M.A.K. (2020). Studying the Intensity and Storm Surge
Phenomena of Tropical Cyclone Roanu (2016) over the Bay of Bengal using NWP model. Journal of Scientific Research, 12(1):55-68.

Fan, J., Zhang, R., Li, G. and Tao, W.K. (2007). Effects of Aerosols and Relative Humidity on Cumulus clouds. Journal of Geophysical Research: Atmospheres, 112(D14).

Basnayake, B.R.S.B., Akand, M.A.R. and Nesa, F.F., (2010). Structure and Movement of Very Severe Cyclonic Storms over the North Indian Ocean simulated by WRF-ARW Model. SAARC Meteorological Research Centre (SMRC) (Vol. 33). 
